\title{
Effects of Poor Supervision on the Sustainability of Micro-Financial Instutions in Ghana (A Focus on Nkoranza Municipality in the Brong Ahafo Region)
}

\author{
Owusu Alfred, Amo Francis \\ Marketing Department, Kumasi Technical University, Kumasi, Ghana \\ Email address: \\ alfredowusu76@yahoo.com (O.Alfred)
}

\section{To cite this article:}

Owusu Alfred, Amo Francis. Effects of Poor Supervision on the Sustainability of Micro-Financial Instutions in Ghana (A Focus on Nkoranza Municipality in the Brong Ahafo Region). Advances in Sciences and Humanities. Vol. 2, No. 3, 2016, pp. 17-30.

doi: $10.11648 /$ j.ash.20160203.11

Received: September 26, 2016; Accepted: October 28, 2016; Published: November 23, 2016

\begin{abstract}
Micro financial institution undoubtedly helps to bridge the gap between the rich and the poor in the community. This is because the poor gets financial assistance through the various products rolls out by these institutions and therefore being termed as banking for the poor, and Nkoranza municipality has been left out. However, MFIs in the Nkoranza municipality have been a source of worry as most of these institutions have folded up less than five years of their establishment. It is against this backdrop that the study focuses on the effects of poor supervision on the sustainability of MFI in Ghana. Both primary and secondary sources of data as well as interview guide were used for the study. The study find out that the main causes of this menace is about poor internal and external supervision by both management and the regulatory bodies on the activities of these failed MFI. Diversion of funds as well as corrupt practices by management and some officials from Bank of Ghana also accounted for the failure of these MFI.
\end{abstract}

Keywords: Micro Financial Institution, Nkoranza, Internal and External Supervision, Bank of Ghana

\section{Background of the Study}

Failure is an option if success is just matter of trying harder (Palahniuk, 2011). The institutionalization and sustainability of organisations is a choice by man. The 16th and $17^{\text {th }}$ century brought the birth of microfinance in Europe against the backdrop of tremendous increases in poverty (Seibel 2005). In a number of European countries microfinance evolved from informal beginnings during the eighteenth and nineteenth centuries as a type of banking of the poor, juxtaposed to the commercial and private banking sector. Almost from the onset, microfinance meant financial intermediation between micro savings and microcredit, and was powered by intermediation (Seibel 2005). In the mid1990s it was taken up by, the donor Consultancy Group to Assist the Poor, (CGAP) which has turned the microcredit revolution into the microfinance revolution and professionalized microfinance. This notwithstanding, microfinance has emerged globally as a leading and effective strategy for poverty reduction with the potential for far- reaching impact in transforming the lives of poor people. It is argued that microfinance can facilitate the achievement of the Millennium Development Goals (MDGs) as well as National Policies that target poverty reduction, women empowerment, assisting vulnerable groups and improving standards of living. As pointed out by the former UN Secretary General Kofi Annan during the launch of the International Year of Micro Credit (2005). AClearly access to financial services is imperative for the development of the informal sector and also helps to mop up excess liquidity through savings that can be made available as investment capital for national development (World Bank, 1999). The first formal micro finance institution in Ghana arose out of the micro savings product of the Post Office system. The institution was upgraded to the Post Office Savings Bank under the Savings Bank Act 1962 (Act 129), to operate independently within the Post Office system. It attained full bank status as National Savings and Credit Bank in 1972 under National Redemption 
Council (NRC) Decree 38. (Anin, 2001). Susu is said to have originated in Nigeria and spread to Ghana from the early 1900 s. In the market places of West Africa, individual 'mobile bankers' help traders and others accumulate savings through small daily deposits (Aryeetey, 1994).

Rosenberg (2004) argue that the poor are generally excluded from the financial services sector of the economy so micro-financial institutions (MFIs) have emerged to address this market failure. Nkoranza Municipality is no exception in this global discovery of bridging the gap between rich and poor through micro-finance institutionalization. However, micro-financial institutions in Nkoranza municipality in Bron-Ahafo Region of Ghana, for past five years have been experiencing folding-ups due to poor supervision. Mills (1997) asserted that supervision has direct effect on staff performance. Supervisors assign task and clear responsibilities of performing those tasks and they in turn expects accuracy and punctuality from assignees. Also supervision gives the right direction to people under supervision to enable them to take initiative and responsibilities to go ahead on their own. Supervision seeks to equip individuals with the necessary knowledge, attitudes and skills to make them useful; not only to themselves but their immediate community and country. If supervisors have the responsibility of improving staff performance by equipping them with knowledge, interpersonal skills, and technical skills then one will say that organisations cannot do without supervisor's involvement. Lack of proper supervision affects the sustainability of these micro-financial institutions in Nkoranza and has become a nightmare to the people of Nkoranza. Boateng (2015) postulated that, Nkoranza municipality has for some time, now been unstable after the suspension of operation of some micro-finance institutions such as Diamond Micro-finance limited (DKM), God is Love fun club, Care for Humanity, and Little Drops fun club by the Bank of Ghana (BoG). Moreover, this incident triggered the boycott of district level elections in the Municipality dated September 2015, and postponed indefinitely due to insecurity.

Against this rapid growth of the collapse has led the researcher to find the causes, effects and some possible solutions to this emerging trend poor supervision.

Although supervision has always been integral to every organization in Ghana, it has either been ignored or received with little attention in the past years. It is an undisputable fact that, micro financial institutions help to bridge the gap between the poor and the rich and its importance cannot be over emphasized. However the sustainability of these institutions leaves much to be desired especially in Nkoranza Municipality of Ghana. The available literature shows that for the past five years, over five micro financial institutions have folded up in the said municipality. Some of these institutions include; Noble Dream Financial Institution, DKM Financial Institution, God Is Love Fun Club, Little Drop, among others. It's against this backdrop that the researcher intends to find out the effects of poor supervision on the sustainability of micro financial institutions in
Nkoranza municipality.

The study seek is to find out the effect of poor supervision on the sustainability of micro financial institutions in Ghana.

\section{Literature Review}

\subsection{Concept of Micro-Finance}

Microfinance has a long history. Traditionally, in the ages past, the poor have been accessing financial services from moneylenders, family and friends. The financial services from these sources are characterized by the charging of exorbitant interest rates, and are sometimes unreliable in times of need. Whence, the emergence of institutional microfinance schemes in the past.

Microfinance has been defined by different scholars in different ways. Baten (2009) discussed micro finance as the provision of a broad range of financial services such as deposits, loans, payment services, money transfers, and insurance to poor and low-income households and, their micro enterprises. Furthermore, Microfinance Information Exchange (MIX, 2010) defines microfinance as a variety of financial services that target low-income persons, particularly women. Richard (2007) posits microfinance as a range of innovative financial arrangements designed to attract the poor either as borrowers or savers. According to Ghartey (2007), microfinance relates to the provision of financial services (i.e. savings, credit, insurance and remittances) to a larger number of the productive but resource poor, in a costeffective and sustainable manner with the view to creating wealth and reducing poverty.

Ledgerwood (2013) discussed that, the microfinance sector now reflects the multidisciplinary intersection of finance, technology, and development, where new ideas are changing the art of what is possible. The actors reflect this diverse ecosystem and include everything from mobile operators to microfinance institutions to community networks. Increasingly, best practice in microfinance is responsible finance, defined as the delivery of retail financial services in a transparent, inclusive, and equitable fashion.

Baten, (2009) postulated Microfinance as "the provision of a broad range of financial services such as deposits, loans, payment services, money transfers, and insurance to poor and low-income households and, their micro enterprises". In the past, unethical moneylenders with extremely high interest rates have been the poor person's only source of capital due to the unwillingness of the formal banking sector to lend without any form of collateral backing.

Seibel (2005) asserts microfinance as a sphere of finance comprising microcredit, micro savings and other microfinancial services. He also used it as a synonym for financial intermediation between micro-savers and micro-borrowers or micro investors. He further discussed microfinance as that part of the financial sector which comprises formal and informal financial institutions, small and large, that provide small-size financial services to the poorer sections of the population as well as larger-size financial services to agro- 
processing and other small and medium rural enterprises. It covers a wide array of microfinance institutions (MFIs), ranging from indigenous rotating savings and credit associations (RoSCAs) and financial cooperatives to rural banks and agricultural development banks. Only a small number of MFIs have the status of a non-governmental organization (NGO) or have the support of donors.

Microfinance institution (MFI) is defined by Ablorh (2011) to consist of agents and organizations that are engaged in relatively small financial transactions using specialized, character based methodologies to serve low-income households, micro enterprises, small farmers, and others who lack access to the banking system. He claims that many MFIs provide social intermediation services such as group formation, development of self-confidence, and training in financial literacy and management capabilities among members of a group in addition to the financial services provided. Although some MFIs provide enterprise development services such as skills training, marketing, and social services, such as literacy training, proper home management and health care, they are not generally included in the definition of microfinance, (Ablorh, 2011). Microfinance is the provision of a broad range of financial services such as - deposits, loans, payment services, money transfers and insurance products - to the poor and lowincome households, for their microenterprises and small businesses, to enable them to raise their income levels and improve their living standards. The birth of microfinance in Europe dates back in $16^{\text {th }}$ and $17^{\text {th }}$ century brought tremendous increases in reduction of poverty and also served as means of bridging the gap between rich and poor. In response, microfinance in a number of European countries evolved from informal beginnings as a type of banking with the poor, juxtaposed to the commercial and private banking sector. Almost from the onset, microfinance meant financial intermediation between micro-savings and microcredit, and was powered by that intermediation. Legal recognition, prudential regulation and mandatory supervision evolved in due course and led to a process of mainstreaming during the twentieth century when microfinance became part of the formal banking sector. However, in one case, that of Ireland, regulation has also been used, upon the initiative of commercial banks, to curtail the further growth of microfinance (Seibel 2005). In Germany, the former microfinance institutions now account for around 50\% of banking assets; outreach is to around $90 \%$ of the population.

Microfinance in Asia presumably has a much longer history, though little seems to be known about the early history of the hui in China, the chit funds in India, the arisan in Indonesia or the paluwagan in the Philippines, to name but a few. Financial institutions of indigenous origin, most of them informal, are still exceedingly widespread but have been largely ignored in financial sector development. There are exceptions on a limited scale, as in India where chit funds are regulated and in Indonesia with its highly diversified rural and microfinance sector where various forms of informal financial institutions have been registered and eventually regulated throughout the twentieth century. Not a single country has made indigenous forms of microfinance a pillar of its modern financial system (Seibel 2005).

Microfinance is not a recent development, and neither are regulation and supervision of microfinance institutions (MFIs). Every now developed country and some developing countries, particularly in Asia, have a long history of microfinance. It is important to recognize this because it presents a view different from that of many in the microfinance community who associate microfinance with credit NGOs and believe that microfinance was invented in Bangladesh some thirty years ago. We first take a look at the microfinance history of two European countries, Ireland and Germany. There are good reasons for that:

(i) Attributing the origin of microfinance to recent initiatives misses the historical depth and scale of microfinance. As a consequence, centuries of experience, of learning from trial and error, failure and success in the past are being missed.

(ii) Conducive policies in several European countries have created an environment in which small microfinance beginnings have evolved into vast networks of local financial institutions which are now part of the formal banking system.

(iii) This may present a vision to those who may think that microfinance is a poor solution for poor countries to be replaced by large commercial banks once development takes off.

Informal finance and self-help have been at the origin of microfinance in Europe. Realizing how informal finance evolved into a major part of the banking system and contributed to poverty alleviation and development may induce policymakers, donors and researchers to take a fresh look at indigenous and informal finance in the developing world. We then take a look at the long and complex and sometimes warped history of microfinance and banking in India. Seibel (2005) further postulated that, the case of India shows that the origins of microfinance predate those reported above in Ireland and Germany by more than two and perhaps even three millenniums. There are at least three strands of indigenous finance of great historical depth in India: moneylenders, chit funds or rotating savings and credit associations (ROSCAs), and merchant bankers - each with a complex and interlinked history, much of it yet to be written. To draw lessons from this experience would require systematic historical research from a microfinance perspective. The following may serve as an inducement to embark on such research and share the results with the microfinance community. This is all the more important as India, over a period of three thousand years, has spread its culture, trade and banking through vast parts of south and south-east Asia and may continue to do so as far as its latest rural finance innovation is concerned: SHG banking.

Moneylenders who provide loans from their own resources as their only financial service are the oldest of these professions, dating back to prehistoric times. There was probably a long period of transition from gift-exchange, 
reciprocal lending and trading-cum-lending to specialized lending, and from lending-in-kind to lending-in-money before the first millennium B.C. Money lending became an organized and subsequently regulated profession in India around 1700-2200 years ago as shown below. Information on rural money lending in medieval and British India will be given below. Money lending is still widespread today, and remnants of its historical informal precedents are still in existence, re-emerging time and again according to demand. Many (informal and formal) moneylenders may have turned into (formal) merchant bankers at various times in history, or into organizers of (informal or formal) chit funds; this is a subject on which I have no information.

\subsection{The Evolution of Micro-finance in Ghana}

Bank of Ghana Working Paper on microfinance (2007) postulated that, certainly, microfinance is not a new concept in Ghana. It has always been common practice for people to save and/or take small loans from individuals and groups within the context of self-help in order to engage in small retail businesses or farming ventures. Anecdotal evidence suggests that the first credit union in Africa was probably established in Northern Ghana in 1955 by the Canadian Catholic missionaries that were there at the time. However, Susu, which is one of the current microfinance schemes in Ghana, is thought to have originated in Nigeria and spread to Ghana from the early 1900s. Over the years, the microfinance sector has thrived and evolved into its current state thanks to various financial sector policies and programs such as the provision of subsidized credits, establishment of rural and community banks (RCBs), the liberalization of the financial sector and the promulgation of PNDC Law 328 of 1991, that allowed the establishment of different types of non-bank financial institutions, including savings and loans companies, finance houses, and credit unions etc.

Currently, there are three broad types of microfinance institutions operating in Ghana2. These include:

- Formal suppliers of microfinance (i.e. rural and community banks, savings and loans companies, commercial banks)

- Semi-formal suppliers of microfinance (i.e. credit unions, financial non- governmental organizations (FNGOs), and cooperatives;

- Informal suppliers of microfinance (e.g. Susu collectors and clubs, rotating and accumulating savings and credit associations (ROSCAs and ASCAs), traders, moneylenders and other individuals).

According to United Nations report on poverty (2009) hypothesized that; Ghana cannot be isolated from the disturbing continental statistics on poverty. Thus at the 2006 UN World Summit for Social Development, poverty was identified to entail the lack of income and productive resources, hunger and malnutrition, ill health, limited or lack of access to education and other basic services. The other indicators are homelessness or inadequate housing; unsafe environments, social discrimination and exclusion in a given social context (UN Report 2009). In effect, any person confronted with most of or all the above indicators can therefore be described as poor. In the wake of these social and economic conditions, access to financial services was limited to the poor. According to international journal of humanities and social science (2013) posit that, the poor households in Ghana could not only meet basic mainstream financial banking requirements for loans and savings but also found their services expensive to deal with cited (Alabi et al 2007). Worst still, informal sources of financial services were equally expensive and unreliable. Pro-poor development policies and programs were designed by NGOs and government over the years to the poor in the Northern Region and other regions of the country. These intervention programs include food-for-education, food-aid, schooluniform-for-education, and microfinance programs to reduce their socio-economic challenges.

The Bank of Ghana report (BOG, 2009) acknowledges the potential contribution of microfinance to the development of the national economy but decries the lack of data on the impact. According to the BOG, microfinance can facilitate the achievement of the Millennium Development Goals (MDGs) as well as national policies that target poverty reduction, empowering women, assisting vulnerable groups and improving standard of living. However, the lack of data on their operations affects the monitoring and evaluation of the impact of microfinance schemes on informal economic activities across the country.

Bank of Ghana (2007) cited (Otero, 1999) discussed that, empirical studies have shown that micro-finance helps very poor households to meet basic needs and protects against risks, and is thus associated with improvements in household economic welfare. Gender activists also argue that microfinance helps in empowering women by supporting women's economic participation and so promotes gender equity.

Other strands of the literature suggest that micro- finance creates access to productive capital for the poor, which together with human capital, addressed through education and training, and social capital, achieved through local organization building, enables people to move out of poverty. By providing material capital to a poor person, their sense of dignity is strengthened and this can help to empower the person to participate in the economy and society.

Owusu A. A, Oppong A., Agyeiwaa D. and Abruquah L. (2015) put forward that, the introduction of microfinance into Ghana has made it possible for operators of small businesses to access credit facilities which hitherto were difficult to access due to difficult modalities by the formal financial institutions. Microfinance provides people with capital to start and or expand their businesses. Small businesses with microfinance support have grown into Medium Enterprises creating employment opportunities for others. Microfinance Institutions (MFIs) currently provide financial services to an estimated 15 per cent of the country's total population as compared with 10 per cent for the commercial banking sector (Obuasi and Polio, 2010). In view of this, the role of microfinance institutions in developing local economies cannot be over emphasized 
especially in developing countries like Ghana (Ntiamoah et al, 2014). However, heart-warming the intervention of MFIs may be, the incidence of high loan default rate among MSME lending seems to be undermining the continuous financing of MSMEs by MFIs in Ghana. The issue of loan delinquency/default among banks and Microfinance Institutions has been discussed in many public lectures and for a as one of the reasons why commercial banks have not shown much interest in financing MSMEs (Addae- Korankye, 2014). According to Balogun and Alimi (1990), as cited in (Owusu et al 2015) loan default is the inability of a borrower to fulfil his or her loan obligation when due. As observed by AddaeKorankye (2014), high default rates in MSMEs lending is a major concern to policy makers in developing countries, because of its unintended negative impacts on MSMEs financing. Microfinance institutions all over the world including Ghana are faced with the challenge of loan default/delinquency. According to Warue (2012), the most common and often the most serious vulnerability in microfinance institution is the chance that a microfinance institution (MFI) may not receive its money back from borrowers (plus interest). The sustainability of microfinance institutions depends largely on their ability to collect their loans as efficiently and effectively as possible. In other words to be financially viable or sustainable, microfinance institutions must ensure high portfolio quality based on $100 \%$ repayment, or at worst low delinquency/default, cost recovery and efficient lending (Addae-Korankye, 2014). AddaeKorankye (2014) further reports in a study in Ghana involving 25 MFIs that, $60 \%$ of the MFIs have their default rates more than the internationally acceptable rate of $3 \%$. This situation poses serious threats to the operations and sustainability of these MFIs which are the financial backbone of Micro, Small and Medium Enterprises in Ghana.

With almost thirty per cent of Ghanaians living below the poverty line, microfinance has been identified as an important means of providing financial services to the population. It is therefore not surprising that the country's present and past governments have perceived microfinance as central to achieving the greater goal of poverty reduction.

Through microfinance, the various governments have aimed to provide the poor, who do not have access to the formal financial sector, with greater access to customized financial services (Adjei, 2010). The Government of Ghana is committed to the goals of the Millennium Development Goals and one of the strategies is the building of a robust and sustainable microfinance industry which addresses poverty reduction, women's empowerment and household welfare. Micro-entrepreneurs constitute about $66 \%$ of the labor force in the country and, thus, represent a vital economic force. (Adjei, 2010) Increasing the access to financial services by this group deepens the financial sector and also links them to the economic mainstream. Indeed, the concept of microfinance is not new in Ghana.

\subsection{The Regulatory Bodies of Micro-finance in Ghana}

There needs to be dialogue on the formulation, implementation and review of regulatory and supervisory policies and procedures to ensure consistency and efficient approaches to regulation across different types of microfinance institutions. Ledgerwood J., Earner J., and Nelson C. (2013) discussed the term regulation as different types of formal legal edicts and pronouncements by government, all of which are published or otherwise made public. This includes primary legislation (that is, laws adopted by the legislature), secondary legislation (that is, circulars, regulations, or guidelines issued or adopted by the regulator), executive orders, declarations, decrees, and other similar enactments and issuances. Typically primary legislation designates and authorizes a government authority to issue secondary legislation. For example, the banking law may designate the central bank as the regulatory authority for banks. A microfinance law may designate a specialized financial authority as the body responsible for regulating microfinance institutions (MFIs). Primary legislation typically can be changed only by the legislature, whereas secondary legislation (such as regulations) can be changed by the regulatory authority. Some regulation may be enforceable in court by private parties; some may be enforceable only by a government agency.

According to Lidgerwood el al (2013) Many areas of law and regulation impact financial services, financial service providers, and clients: Banking law (that is, primary and secondary legislation) applies to banks and sometimes to other depository institutions (in which case other possible names may be used, such as "financial institutions law"); non-profit law is often relevant to nongovernmental organization (NGO) MFIs; financial cooperatives are often subject to a specific law on cooperatives, although in some countries they may also be subject to a specific finance law (for example, non-bank financial institutions law); insurance law governs insurance companies; leasing law covers leasing companies; the commercial code or companies law will typically apply to for-profit financial entities as well as nonprofit companies (where they exist); and payment systems law generally governs the payment infrastructure (and may also cover payment service providers and e-money issuers, either directly or as elaborated in regulations adopted under such law). Financial consumer protection regulation should apply ideally to all financial service providers. Other areas of law that may be relevant to financial ser- vice providers include competition law, secured transactions/collateral registries, anti-money laundering and combating the financing of terrorism (AML/CFT), insolvency, capital markets, property rights, and foreign direct investment. The regulatory environment can have significant impact on the particular models of financial service delivery and the possibility of developing innovative approaches. Registration and licensing: Registration typically involves filing basic information with a government body designated as the registrar (for example, non-profit registrar, MFI registrar, or cooperative agency). Basic information includes the provider's name, address, and constituent documents (for example, articles of association or foundation, by-laws) and 
sometimes the names of the founder(s) or owners, senior management, and members of the board of directors (Lidgerwood el al 2013).

They further discussed that; Licensing may be required to operate as a specific type of institution. (Some jurisdictions use the term "permit" instead of license.) Banks and other deposit-taking institutions, e-money issuers, and payment service providers are required to be licensed. In some countries, lending-only institutions are also required to be licensed or "permitted." To be licensed, an application must be submit- ted to the regulator that oversees or supervises the specific institutions that are licensed. The application usually involves submission of various documents, including a threeor five-year business plan, operational policies and procedures, evidence that proposed senior management, board members, and significant owners (that is, those with an ownership interest exceeding a specified percentage) meet fit and proper criteria, and demonstrated ability to meet the regulatory minimum capital requirement. In some cases a deposit of funds must be made at the time the application is submitted. An applicant for a banking or similar license may also be required to demonstrate that it meets the following requirements: well-designed and implemented risk management policies and procedures, an effective audit function, secure branches, contingency plans, diverse ownership, and evidence that the core banking system and other technology requirements are adequate. A licensed institution in some countries may be required to seek additional licenses to engage in certain activities (for example, foreign currency trading) (Lidgerwood el al 2013).

\subsection{Challenges Facing the Microfinance Sector}

Generally, since the beginning of government involvement in microfinance in the $1950 \mathrm{~s}$, the sub-sector has operated without specific policy guidelines and goals. This partially accounts for the slow growth of the sub-sector, and the apparent lack of direction, fragmentation and lack of coordination. There has not been a consistent approach to dealing with the constraints facing the sub-sector. Such constraints include - inappropriate institutional arrangements, poor regulatory framework, inadequate capacities, lack of coordination and collaboration, poor institutional linkages, lack of linkages between formal and informal financial institutions, inadequate skills and professionalism, and inadequate capital etc. For example, better coordination and collaboration among key stakeholders including development partners, government and other agencies, could help to better integrate microfinance with the development of the overall financial sector.

Secondly, traditional commercial banking approaches to microfinance delivery often do not work. According to traditional commercial banking principles, the credit methodology requires documentary evidence, long-standing bank- customer relationship and collateral, which most micro and small businesses do not possess. The commercial banking system, which has about twenty-three (23) major banks, reaches only about $5 \%$ of households and captures
$40 \%$ of money supply. Therefore there is room for expanding the microfinance sector in Ghana.

An example is the program for Susu by the Barclays Bank of Ghana (BBG) Ltd. BBG launched a micro banking scheme in December 2005 which establishes a formal link between modern finance and Susu (one of Africa's most ancient forms of banking) collection in an unconventional mobile initiative across the country. The scheme aims to extend microfinance to some of the least affluent in Ghana, like the small trader at the market or the micro-entrepreneur selling from road-side stalls. Though their individual income is apparently too small for 'high street' banking, collectively it estimated at about a $\$ 150$ million economy thriving below the traditional banking radar. Ghana's 4,000-strong Susu Collectors offer basic banking to the needy. For a small fee they personally gather the income of their clients and return it at the end of each month, providing greater security for their client's money. In addition, with finance from Barclays the Susu Collectors are able to provide their clients with loans, helping them to establish or develop their business. In the words of the CEO of BBG Margaret Mwanakatwe, It is gratifying to note that the Government of Ghana has adopted microfinance as one of the important strategies for poverty reduction and wealth creation. Recognizing the role various institutions and individuals can play to ensure the achievement of this national vision of achieving the MDGs and also becoming a middle income country by the year 2015 , there is the need to quicken the pace of reforms in the microfinance sector in order to unleash its full potential for accelerated growth and poverty reduction.

Finally, while Ghana has a reasonably diversified and supervised regulatory framework for formal financial institutions licensed by $\mathrm{BoG}$, there is concern that appropriate regulation needs to be extended to other institutions operating in the microfinance sub-sector (for example the legal framework for credit unions) in order to improve the outreach, sustainability and efficiency of savings, facilitate credit delivery, and institutional arrangements. (B.O.G 2007). The key stakeholders of Microfinance institutions in Ghana are the Rural /Community Banks, Savings \& Loans companies, Credit Unions and Financial Non-Governmental Organizations.

\subsection{Effective Supervision}

It is believed that an effective supervisor can be a business most valuable asset. The well trained supervisor who excels at managing employees can make everyone around him or her more effective and efficient. Several supervisory skills directly affect employee's development, helping them to achieve their potential while gaining skills that are valuable to the organisation.

Typically, the performance of each individual should create an impression in the entire organisation and like the business organisations, staff of Ghana Education Service are supposed to contribute effectively in their performance. The performance that each staff might contribute represents the various factors such as the functions and roles assigned to 
them; the organisational structure in which they operate; their workload; and work management. In addition, the performance of the staff can be supervised according to the tasks or responsibilities given to them (Henderson \& Gysbers, 2006). The researcher is in support of this concept in that each individual's work adds up to achieving goals of the organisation. It is therefore crucial for administrators to set standards for the staff to keep them aligned in their field of work or to formulate the kind of motivational approaches to increase the performance of the individual. In support of this, it is clear that the attitudes and competencies of supervisors can influence the staff through training and support provided in their profession. Staff supervision, also known as staff coaching, is described to be one of the components of professional development. This includes the variety of education, training, and development activities. The common goal of staff supervision is to increase the knowledge and skills of the staff in order to facilitate the improvement in their performance (Burkhauser \& Metz, 2009).

The supervisorse ${ }^{\text {ee }}$ roles are also changed and sometimes called as the "advisors" of the staff. The contribution of supervisors in staff performance creates an impact, especially in organising the different services (UNESCO, 2007). Based on the various coaching theories, the supervisor should have the knowledge in the area of the staff and have to build the relationship. This is the reason for which supervisors should build the respect, trust, and collegiality that increase the interaction abilities of the staff. Both staff and the supervisor should engage in wide variety of activities. Through the help of the guidance and supervision program, the staffs are allowed to experiment, practice, and learn through their mistakes. All of the experience that the staff can gather is effective reference or sources for his sole decision making. The school administration should thereby, promote the supervision initiatives with the aim of long-term professional development strategy (Burkhauser \& Metz, 2009) If all supervisors will guide and develop employees or staff, it will go a long way to improve performance.

\subsection{Major Problems in Supervision}

Ultimately, the overarching objective of these multiple tasks and roles is the improvement of both the quality of teaching and the efficiency of the system. But - and this is a recurrent theme in nearly all countries, developed and developing, centralized or decentralized, with autonomous or tightly controlled supervisors - supervision and support services all too seldom achieve that objective. They are facing a certain number of difficulties in their functioning, which greatly reduce their efficiency and their ultimate impact on what is going on in the institution, schools and in the classrooms. Some of the problems are as old as the supervision structures themselves; others are directly linked to recent changes in the ways in which school management is conceived. A fairly long list of interrelated problems is discussed in the existing literature, which will be summarized under different headings. A first set of issues is related to the deterioration of the working conditions under which supervision services operate. Others have to do with more profound conflicts between the different roles which supervisors are asked to play. Finally, a number of difficulties derive from the way in which supervision services are managed and monitored.

\subsection{Factors for Effective Supervision}

Apenteng (2012) put forward the following eight items as effective way of discharging effective supervision.

1. Conducive atmosphere: The environment should be made free of tension and emotional stress. The atmosphere should be given incentives for work.

2. Staff orientation: Orientation is the personnel activity which introduces new employees to an enterprise and to their task, superiors, and workforce do not know the job, how the pattern for supervision, or whom to see to get job done. In view of this, new supervisors should be imbibed into the work system in order to make them effective. The quality and quantity of their work must be specified in clear terms. They should be made to understand clearly what they are expected to do or not. New supervisors must be given the necessary orientation to enable them reach set standards sooner. They should have a schedule to know where to get information and materials to assist them perform their work efficiently.

3. Training: Training is said to be a systematic procedure of altering the behavior of employees in a direction that will achieve organisation goals. Training is related to one's present job skills and abilities. It has a current orientation and helps employee master specific skills and abilities needed to be successful. Ivancevich, (1998). In the light of this, acquisition and using knowledge for effective supervision is critical. In-service training, conferences and workshops which are significant for improving knowledge of supervisors, must be carried out in a way that will equip them with current tools of supervision. Tanner and Tanner (1987 p.206) are of the view that for supervision to achieve its objectives the quality of the supervisor should be considered paramount.

4. Immediate recognition of good work: Good work should be recognised. This implies that the acknowledgement of any good work done must be immediate and made public to others which will then serve as incentive to others. Incentive of merit, recommendation for promotion, etc. improve performances.

5. Constructive criticisms: Supervisors must criticize poor work done by a subordinateconstructively. Advice and personal relationship should be given to the affected staff. It needs be stated here that such criticisms should be made private and with clear mind.

6. Opportunity for improvement: Supervisors should give opportunity to subordinates to prove their worth and for aspiring higher. They should therefore be allowed to use their initiatives in performing their jobs and taking decision. It will give them the motivation to work much harder.

7. Provision of logistics: Logistics are the engine on which supervision thrives. Availability of logistics and materials for 
work are critical, in the sense that it creates confidence in supervisors and staff. Lack of logistics can greatly hinder the work of supervisors or slow down progress of work, as motivation is likely to dwindle. Halpin (1956) is of the view that supervision can effectively be carried out when logistics are provided to support it.

8. Team work: Team building is of great importance to any successful business.

Supervisors must collaborate with staff in a manner that will bring all partners together as a team. The team must learn and share a common goal or vision, belief and work together as professional.

The international stakeholders interviewed Strachan (2010) also stressed the importance of the community in monitoring and supervising CBAs. Many of the interviewees proposed the establishment of health committees who supervise and monitor CBAs as an effective way of both engaging the community and encouraging ownership. It was suggested that such groups should review data as it was argued that this allows workers and volunteers to see that they are making a difference which is motivating. An approach suggested as having achieved this end was the Community Based Health Information System (CBHIS) initiated by AMREF with the Ministry of Health in Kabwese in South West Kenya Strachan (2010). Bjorkman\&Svensson, (2009) argue that, effective supervision led to increase in quality and quantity of goods and facilities.

\subsection{Sustainability of Micro-financial Institutions}

Microfinance has become an important tool for poverty reduction in many parts of the world. Microfinance institutions (MFIs) target the poor through innovative approaches which include group lending, progressive lending, regular repayment schedules, and collateral substitutes. But it sustainability in Ghana sometimes needs much to be desired.

Kimando N. L., Kihoro M. J., and Njogu W. G. (2012) hypothesized that, Sustainability is a cornerstone of sound microfinance. They further discussed that, the term refers to the ability of a microfinance institution (MFI) to cover all of its costs through interest and other income paid by its clients. Financially sustainable MFIs can become a permanent part of the financial system: they can continue to operate even after grants or soft loans are no longer available. Donors have nowhere near enough funds to meet the global demand for microfinance. But when an MFI becomes sustainable, it is no longer limited to donor funding. It can draw on commercial funding sources to finance massive expansion of its outreach to poor people. Experience proves that microfinance can be done sustainably, even with very poor clients.

Kimando et al (2012) as cited (Sharma and Nepal, 1997) discussed from bankers ${ }^{\text {ee }}$ perspective, a microfinance institution is said to have reached sustainability when the operating income from the loan is sufficient to cover all the operating cost. This definition adopts the bankers ${ }^{\text {ce }}$ perspective and sticks to "accounting approach" of sustainability as the "accounting approach" to sustainability that takes into account the financial aspect of the institution is too narrow. He states that the concept of sustainability includes, amongst other criteria obtaining funds at market rate and mobilization of local resources. Therefore, the performance assessment criteria for the financial viability of any microfinance related financial institution are: repayment rate, operating cost ratio, market interest rates, portfolio quality, and "demand driven" rural systems in which farmers themselves demand the loans for their project. From bankers perspective, sustainability of microfinance institution includes both financial viability and institutional sustainability (self sufficiency) of the lending institution (Sharma and Nepal, 1997). The terms of reference in bankers definitions are therefore, more financial, administrative and institution focused.

According to Warue (2012), the most common and often the most serious vulnerability in a micro finance institution is the chance that a microfinance institution (MFI) may not receive its money back from borrowers (plus interest). The sustainability of microfinance institutions depends largely on their ability to collect their loans as efficiently and effectively as possible. In other words to be financially viable or sustainable, microfinance institutions must ensure high portfolio quality based on $100 \%$ repayment, or at worst low delinquency/default, cost recovery and efficient lending (Addae-Korankye, 2014). Addae-Korankye (2014) further reports in a study in Ghana involving 25 MFIs that, $60 \%$ of the MFIs have their default rates more than the internationally acceptable rate of $3 \%$. This situation poses serious threats to the operations and sustainability of these MFIs which are the financial backbone of Micro, Small and Medium Enterprises in Ghana. Kohansal and Mansoori (2009) equally agree with Warue (2012) when they said Most of the defaults and lack of sustainability of most micro financial institutions arose from poor management procedures, loan diversion and unwillingness to repay loans and the like.

Sustainability -therefore, Refers to the ability to continue any given activity into the future within the likely existing resources of an organization, as part of its on-going budgetary and management processes.'

\section{Data Presentation, Analysis and Discussion}

\subsection{What Are the Causes of Poor Supervision on the Sustainability of Micro Financial Institution in Nkoranza Municipality}

The purpose of this research question was to identify the causes of poor supervision on the sustainability of micro financial institutions in Nkoranza municipality of Ghana.

TRANSCRIBED INTERVIEWS.

Interviewee one, is a manager, put forward that, one of the causes of folding-ups of micro-financial institutions in Nkoranza municipality is "Improper internal supervision by 
the organisation". The management of these failed micro financial institutions failed to put in proper mechanism to check activities of their employees. He further on postulated that, theses MFI employed their relatives and friends who they fail to sanction when they abused the system and also promote lack of proper supervision in the organisation.

Interviewee two was a client to God is love microfinancial institution, and DKM micro-financial institution in Nkoranza municipality. He was a teacher by profession, he posit that, "The government failed to carry out its responsibilities as he put it negligence of duty by the government". To the interviewee, he waited for some time for about three years before he joined the micro financial institution in order to see its authenticity. He said, "It was official from Bank of Ghana (BOG) together with soldiers who came to close down these institutions". Therefore, he attributed the cause of folding ups to the government. Hence, he was an eye witness to the closure of God is love micro financial institution. He also said, I collected a loan from banks to invest in these institutions and when I go to bank there is no money for me to take home.

Interviewee three, an employee of DKM micro-financial institution discussed that, the causes of collapse was due to high interest rate to clients, because these institutions did not do their feasibility work well. She also emphatically stated that, she also agreed to the poor supervision as one of the failures of the MFI. To her, "the regulatory bodies did not do their work well because it fails to organise supervision intermittently". She said it had had negative effect on the banks because most of the customers have lost faith in banking sector in the Nkoranza municipality which has affected savings and depositing in the municipality especially by peasant farmers and the traders as most of them still keep their monies under their pillow.

Interviewee four, is a manager, discussing the causes of the folding ups of some micro-financial institutions in Nkoranza said, "Managerial failure", that is managements of these institutions started given out loans to their clients early without waiting for enough maturity of the institution. The needed check which was to be done on the client credit worthiness was not carried out properly due to unhealthy competition among the MFI in the municipality. "Weak capital base is also another cause of the failure of the MFI". Some of these monies were used as capital expenditure. They spent some on fixed assert which does not yielded any interest and the exorbitant cost of their rented premises. He also said supervision is another problem because; most of these institutions just open branches without any proper documentation and the necessary capital to operate. Panic withdraws also caused the folding up of MFI said by him.

The Interviewee five, an agent to God is Love microfinancial institutions; put forward that, "Competition has caused these institutions. There was unhealthy competition among the MFI by promising outrageous benefits which later they find it difficult to pay to their customers". He further expatiated that, the promise of fat interest to clients brought about the unhealthy competition which fuel the emergency collapse of these micro financial institutions.

The interviewee six is worker of God is love microfinancial institution; he put forward that, "Freezing of the account of God is love fun club by BoG. Before the account was freezed, the institution was operating effectively". The interviewee apportions the blame on the Bank of Ghana that, they diverted the funds into different thing.

The interviewee seven is worker at one of the credit union at Nkoranza; also re-iterated that, "High interest rate brought down collapse of these institutions. They failed to obey the laid down rules and regulations of the Bank of Ghana". He recounted several promises made by these micro financial institutions with the aim of getting more client base in order to stay in the business and or amass wealth. He mentioned that, some promised 70 per cent, 80 per cent respectively, whiles even in the initial stages some gave out 100 percent profit to clients on the base of saving for two months. This luxurious interest paid by these micro financial institutions attracted a lot of customers like teachers, nurses, business men and women, farmers to extent of withdrawing their savings from the traditional banks and kept them in these institutions. Therefore, having had broad base customers and keeping their promise by paying the interest drained them which might have caused it to collapse.

Interviewee eight is a trader and client to Little Drop micro financial institution, posit that, "Unfaithfulness among the management of MFI. These firms management were not truthful. According to the interviewee, when some of the BOG supervisors came to audit these MFI, because of their dubious activities and lack of transparency they were kept in expensive hotels at Sunyani and collected bribes and because of that they failed to report the exact situations to the Bank of Ghana. That is why they were able to operate for nearly four years in the municipality. Therefore corruption and unfaithfulness on the part of MFI management and Bank of Ghana supervisors from the region have actually caused the folding up of these MFI".

The interviewee nine is a worker at existing Multi Credit financial institution, hypothesized that, deposit mobilization by the MFI. These MFI go outside their jurisdiction and collect money without due recourse to the law. He also shares the view that the capital based of these MFI was inadequate and poor supervision cannot be left out. "That is when the certificate of mobilization was given out to these institutions by BOG; they never came out to inspect their activities and operations. However, the next time we heard about them was the enclosure of these institutions".

According to the tenth interviewee is reporter and a client to God is Love micro finance, put it that, negligence of duty by BOG and government is the cause. To him the closure of MFI by the government is the main cause of the folding up.

In addition to these interviews, questionnaires were also administered to solicit data and these are analysed below: 


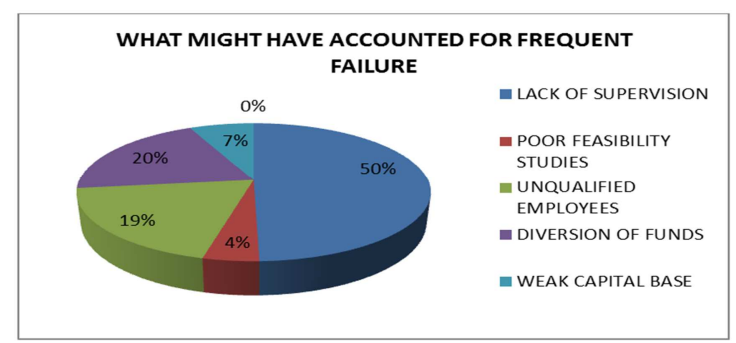

Source: field data 2016

Figure 1. What might have accounted for frequent failure.

From the figure 1 above, the researcher was trying to find out the cause of the folding up of the micro financial institutions in Nkoranza municipality. The results from the data present that, the majority $(50 \%)$ of the respondents represent lack of supervision, $20 \%$ represented diversion of funds, $19 \%$ of the respondents represented unqualified employees, $7 \%$ for weak capital base while $(4 \%)$ out of the total number represent poor feasibility studies. The result from the data shows that, lack of supervision is the cause of the collapse of micro financial institutions in Nkoranza municipality.

Ledgerwood el al (2013) opines that, effective supervision is critical to ensuring a well-functioning financial sector. They further put forward that, when a provider is subject to prudential supervision, the implication is that a governmental body is ensuring that the risks being taken by the institution are not subject to undue risk of loss. The result also in line with interviewees one and eight whose put forward that lack of proper supervision and diversion of funds contributed to the folding ups of MFI in Nkoranza. In support of this, Daily guide, Friday, May 20, 2016 page 8 posit, Dr. Issahaku the governor of Bank of Ghana who intended that, the monies of the collapsed micro financial institutions were diverted, and therefore, the funds in DKM accounts could not offset the companies liabilities to depositors.

The researcher is in support of this concept in that each individual's work adds up to achieving goals of the organisation. It is therefore crucial for administrators to set standards for the staff to keep them aligned in their field of work or to formulate the kind of motivational approaches to increase the performance of the individual. In support of this, it is clear that the attitudes and competencies of supervisors can influence the staff performance through training and support provided in their profession.

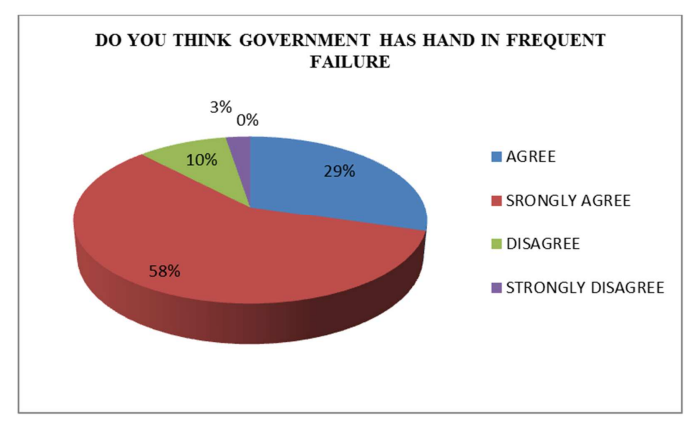

Source: Field data 2016

Figure 2. Does Government has a hand in the frequent failure of MFI.
The results of the study presented in Figure 2 show that as many as $58 \%$ of the respondents were strongly agree that government has hand in frequent failure of micro financial institutions in Nkoranza municipality, 29\% of the respondents were agree, $10 \%$ disagree while $3 \%$ of the total respondents strongly disagree. This can be inferred that majority of the respondents strongly agree that government plays role in the collapsing of the micro financial institutions in Nkoranza.

According to Bank of Ghana official website (2007) Opine that, since the beginning of government involvement in microfinance in the $1950 \mathrm{~s}$, the sub-sector has operated without specific policy guidelines and goals. This partially accounts for the slow growth of the subsector, and the apparent lack of direction, fragmentation and lack of coordination. This confirms the interviewees; two, six and ten who put forward that, "The government failed to carry out its responsibilities as they put it negligence of duty by the government". Negligence of duty by BOG and government is the cause. The researcher inferred that, the regulatory bodies could be a contributing factor of the collapse.

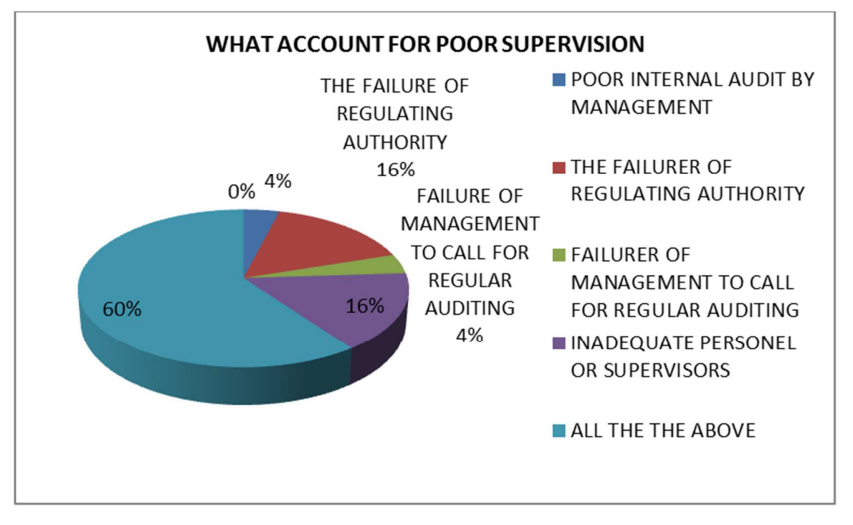

Source: field data 2016

Figure 3. What account for poor supervision.

Figure 3 represents respondents 'opinion on what accounted for poor supervision as a cause of folding ups of micro financial institutions in Nkoranza. From the result, $60 \%$ of the responses represent all the above, $16 \%$ for inadequate personnel, $16 \%$ represent failure of regulating authority, $4 \%$ for poor internal audit by the management, while another $4 \%$ represent the failure of management to call for regular auditing. The majority of the respondent responses indicated that, failure of regulatory authority, inadequate personnel or supervisors, poor internal audit by management and failure of management to call for regular auditing were all accounted for the collapse of MFI in Nkoranza municipality. Inferably the causes of the collapse can be seen as been intertwined. Therefore, the researcher is of the view the causes were inter-dependent. 


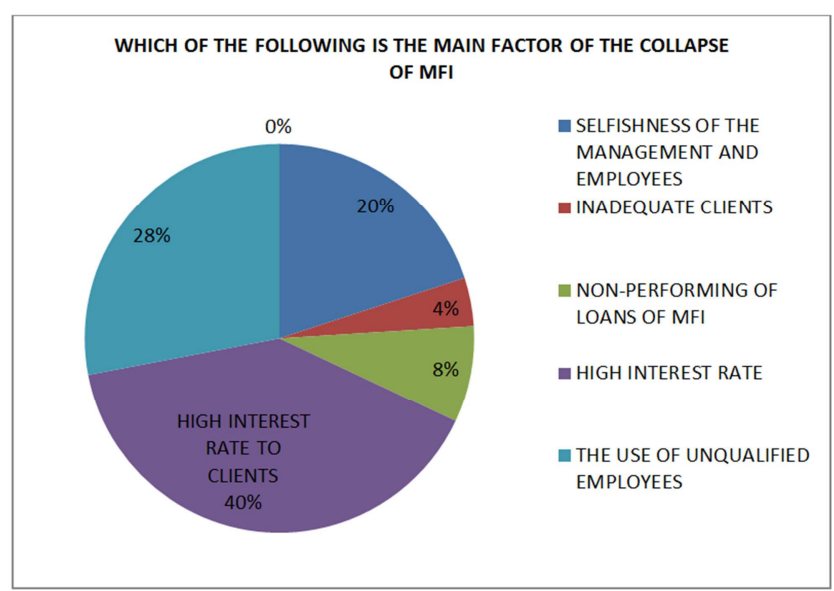

Source: Field data. 2016.

Figure 4. Which of the following is the main factor of the collapse of MFI in Nkoranza.

The results of the study presented in Figure 4 shows that majority of (40\%) represent high interest rate to clients, $28 \%$ of the respondents for the use of unqualified employees, $20 \%$ selfishness of the management and employees, $8 \%$ represent non-performing of loans of MFI, while $4 \%$ represent inadequate clients. The majority of the data responses which is high interest rate to clients is in line with one of the interviewee, the interviewee seven posit that, "High interest rate brought down collapse of these institutions. They failed to obey the laid down rules and regulations of the Bank of Ghana". He recounted several promises made by these micro financial institutions with the aim of getting more client base in order to stay in the business and or amass wealth. He mentioned that, some promised 70 per cent, 80 per cent respectively, whiles even in the initial stages some gave out 100 percent profit to clients on the base of saving for two months. It can be deduced that, based on the outrageous interest rate promised and paid by these MFI drove both learners and illiterates to rush for these investments decisions. It can also liken to shear greediness.

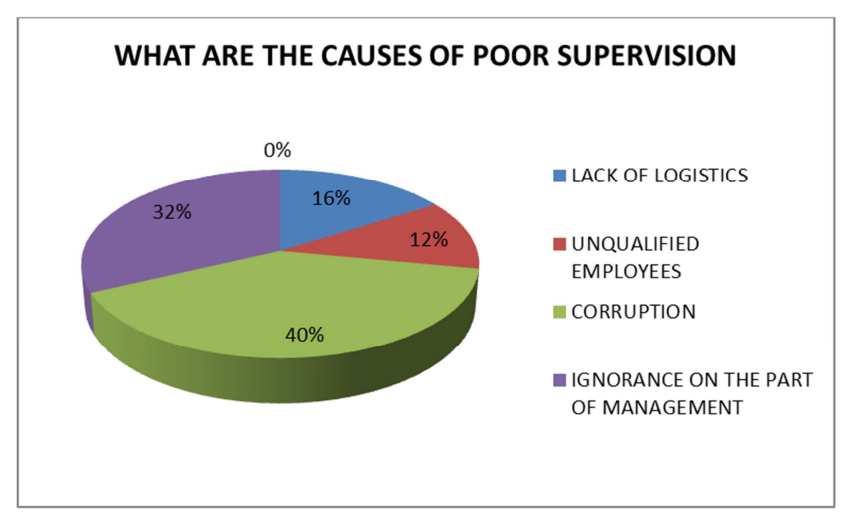

Source: Field data 2016

Figure 5. What are the causes of poor supervision.

Figure 5 presents result on the causes of poor supervision. $12 \%$ of the respondent's responses represent unqualified employees, $16 \%$ represented lack of logistics, and $32 \%$ represent ignorance on the part of management while the majority of $40 \%$ of the respondents represent corruption. From the result, the researcher can therefore, infer that corruption is a cause of the folding ups of these MFI in Nkoranza municipality. This result is also in line with Interviewee eight who posit that, "Unfaithfulness among the management of MFI. These firms management were not truthful. According to the interviewee, when some of the BOG supervisors came to audit these MFI, because of their dubious activities and lack of transparency they were kept in expensive hotels at Sunyani and collected bribes and because of that they failed to report the exact situations to the Bank of Ghana. That is why they were able to operate for nearly four years in the municipality. Therefore corruption and unfaithfulness on the part of MFI management and Bank of Ghana supervisors from the region have actually caused the folding up of these MFI'. The researcher can therefore, inferred that, corruption on the part of some official from Bank of Ghana and the management of the collapsed microfinancial institutions in Nkoranza are some of the causes for ignorantly neglect some of their core duties and collecting bribes respectively.

\subsection{What Are the Effects of Poor Supervision on the Folding up of Micro Financial Institution in Nkoranza Municipality}

The purpose of this research question was to find out effects of poor supervision on the folding ups of micro financial institutions in Nkoranza municipality of Ghana.

The following are the results from interviewees on the effects of collapse on the society and organisations.

The forth interviewee, opine that, the closure of these micro finance institutions have affected trading activities and also created mistrust among the customers and families in the municipality. This menace has even caused some affected natives to resort to keeping their monies under their pillow. Businesses had gone down and affected the local economy.

The interviewee five put forward that, It has caused my job because I kept the money for the daily sale for about three months when my owner travelled at the MFI with aim of getting interest on it and the unexpected happened and they failed to pay my die needed money.

"My owner has collected his car from me". My marriage could not materialize because I could not pay the bride price of my wife.

The interviewee six, a client, discussed that, there has been loss of life. "about 20 customers have passed on due to the collapse of MFI". He also hypothesized that, it has brought about untold hardship on the people living standard, even getting three square meals a day is a problem. Businesses have been affected due to the collapse of MFI and its ripple effects cannot be over emphasized.

The interviewee seven, who happens to be worker of the existing MFI opine that, it has even affected banks and credit unions because most of the clients withdrawn their monies from traditional banks, the Area Credit Unions and deposit them on these MFI. Therefore, these affected banks and 
credit unions eventually gone down because the clients could not prow back their savings and interest and re-invest.

The tenth interviewee with reference to effects posits that, "I have sold my container because of lack of money due to the failure of these MFI". On education, he said, "my two junior brothers have stopped school because I take care of them". He re-iterated that, all his saving had locked up due to the closure of these micro finance institutions issues. He further stated that, marriages have been collapsed due to the unsuspected folding ups of the micro financial institutions in the municipality. He also attributed that, the district assemble elections could not come on due to this folding ups menace in the municipality and further postulated that, no election would be held in this municipality as it happened in the assembly election if the Government failed to get us our hard earned money.

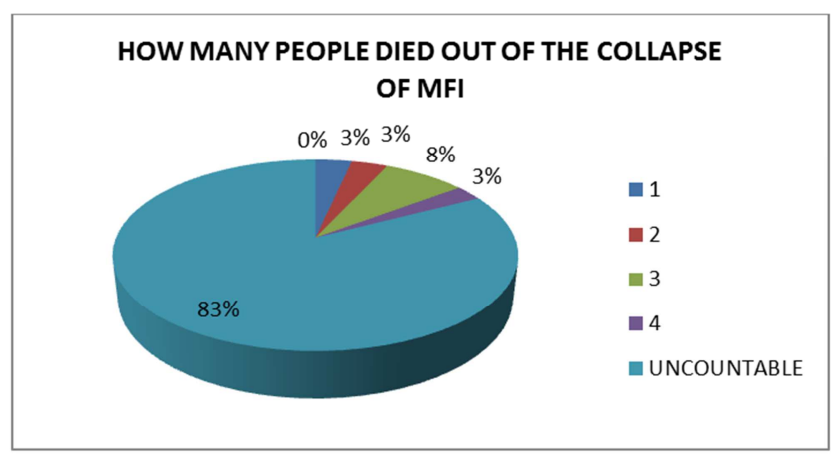

Source: field data 2016

Figure 6. Number who have died out of the collapse of MFI.

Figure 6 analysis data on many times people died out of the collapse of these mentioned micro-finances in Nkoranza municipality. From the result $(83 \%)$ of the respondents represent uncountable, $8 \%$ represent three (3), 3\% represent two (2), $3 \%$ represent (4), while another $3 \%$ represent 1 respondent. This can be inferred that, the number of people died out of the collapse is uncountable. The researcher agreed with the result, in that, there were a lot of people whose death were undisclosed but directly or indirectly linked with the folding ups.

\subsection{How Would the Study Help Curb Frequent Failure of These Institutions}

The purpose of this research question was to help propose some identifiable solutions to curb rampant failure of micro financial institutions in Nkoranza municipality of Ghana

\section{INTERVIEWS}

The interviewee one, posit that, the internal supervision by the organization is paramount to the sustainability of MFI in Nkoranza. He also reiterated that, people must be watching dog especially the managements of these institutions. To him there is difference between knowledge and practice therefore; technical men are needed for the success of the organizations. Customer satisfaction is also important for the survival of these MFI.

The interviewee three hypothesized that, poor supervision was one of the failures of the MFI. To her, the regulatory bodies did not do their work well because it fails to organise supervision intermittently. She said the solution lies on proper supervision of the BOG. She even suggested that BoG should have supervisors in each district in other to check the activities of these institutions.

According to the forth interviewee, "BOG should make sure that these financial institutions follow the laid down rules and regulations. The operators of MFI who are not fake should take their work seriously through proper internal supervision".

He also postulated that, "Customers should also look out for certain things before investing in these institutions; like proper certification and documentation before investing their hard earned money".

The interviewee seven opines that, "Bank of Ghana (BoG) should get staff in every district to monitor these firms and their activities. BOG must also bring the names of registered MFI and educate the people. They should also check the various advert run on the airwaves to see if these institutions or firms meet the criteria of MFI before they run these adverts".

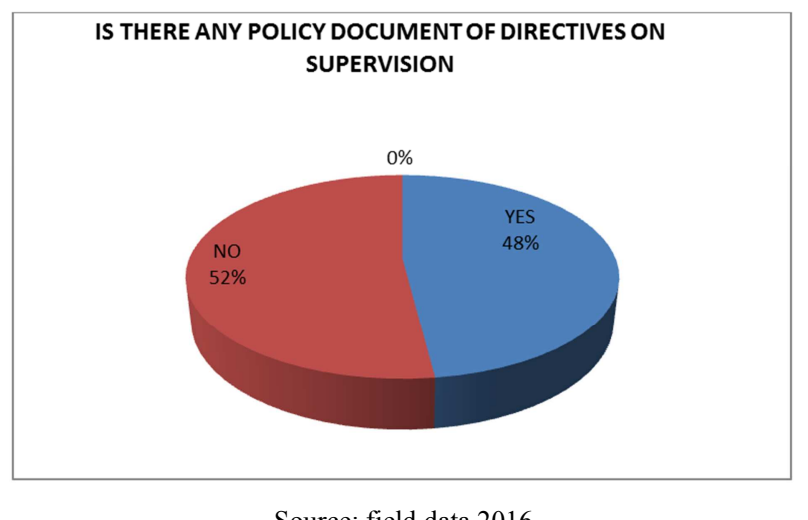

Figure 7. Represents is there any policy document of directive on supervision.

The majority (52\%) of the respondents said No 'while $48 \%$ of the total respondents said _yes'. The result is in line with Bank of Ghana (2007) assertion that, since the beginning of government involvement in microfinance in the 1950s, the sub-sector has operated without specific policy guidelines and goals. This partially accounts for the slow growth of the sub-sector, and the apparent lack of direction, fragmentation and lack of coordination. There has not been a consistent approach to dealing with the constraints facing the sub-sector. Such constraints include - inappropriate institutional arrangements, poor regulatory framework, inadequate capacities, lack of coordination and collaboration, poor institutional linkages, lack of linkages between formal and informal financial institutions, inadequate skills and professionalism, and inadequate capital etc. For example, better coordination and collaboration among key stakeholders including development partners, government and other agencies, could help to better integrate microfinance with the development of the overall financial sector. It can infer that, 
there is no clear cut policy guidelines govern the implementation and sustainability of the micro financial institutions in Ghana. Therefore, in other to ensure better institutionalization, sustainability and smooth running of the micro financial institutions, there should be clear policy document of directives on institutionalisation and supervision to assist success of these MFI from the regulatory bodies.

\section{Conclusion and Recommendations}

\subsection{Conclusion}

Around the globe, micro finance has proved beyond reasonable doubt as a means of bridging the gap between rich and the poor. The emergence of micro finance has evolved and spread in the development community as a development intervention that can meet the special needs of poor people. Ghana is no exception with this global intervention of micro finance as a poverty reduction mechanism. But some parts of Ghana, especially, Nkoranza municipality, micro finance has become a nightmare, instead of helping to reduce poverty, it rather deeping the woes of these vulnerable people by taken away from the poor unlawfully. The causes have been Lack of effective supervision on the activities of these failed micro financial institutions by both the managements and the regulatory bodies (BoG). An unhealthy competition among these MFI's led to the high interest rate given to clients within shortest possible time of investment. Unfaithfulness and corrupt practices indulged by the management and some officials from Bank of Ghana caused the collapse.

\subsection{Recommendations}

After a thorough search, the researcher recommends the following to the police makers and the development practitioners of MFI as well as the clients:

- The regulatory bodies should come out with a policy directive that will guide the activities of MFI. The BoG should give specific years for the MFI to operate before they can diversify toothier business ventures as most of the failed MFI added a lot of business to the MFI. This made them to divert most of the client's contribution to grow such business at the expense of the core business at the expenses of the core mandate. For example DKM extended to transportation, construction and even agriculture without paying attention to the MFI.

- Besides, the management as well as employees of MFI should meet minimum standard of qualification. This is so because even some of management of these failed MFI institution like God is Love micro financial institution were virtually senior high school graduates and even the few degree holders were without any business background.

- There is also the need to decentralize the inspectorate team of Bank of Ghana to the various districts. This monitoring team must be tasked to check the activities of the micro-financial institutions in other to prevent future occurrences. Professional training and development of management of micro-financial institutions should be strictly enforced and monitored by the officials of Bank of Ghana to ensure its sustainability.

\section{References}

[1] Ablorh, W. (2011). Microfinance and socio-economic empowerment of women: A case of Opportunity International Savings and Loans clients. Kwame Nkrumah University of Science and Technology (Unpublished Master's Dissertation), 16-19.

Availableathttp://dspace.knust.edu.gh:8080/jspui/bitstream/12 3456789/4196/1/Ablorh\%20thesis.pdf

[2] Access Africa. (2009). Principles of linkage. CARE Access Africa and Hugh Allen for Access Africa.

[3] Addae-Korankye A. (2014). Causes and Control of Loan Default/Delinquency in Microfinance Institutions in Ghana. American International Journal of Contemporary Research, 4(12).

[4] Adjei, K. J. (2010), Microfinance \& Poverty Reduction: The Experience of Ghana. Africa: A Study of Informal Finance in Ghana, Overseas Development Institute, Africa: Lessons from Linkage Efforts, IMF Institute and the Joint Africa Institute (Paper presented at High-Level Seminar on African Finance for the 21 st Century).

[5] Apenteng. O. J., (2012) the effect of supervision on staff performance in Ga-south municipal education directorate. Thesis, Ghana (Unpublished).

[6] Aryeetey, E., 2008, From Informal Finance to formal Finance in Sub-Saharan.

[7] Bank of Ghana Annual Reports, 2003-2007.

[8] Bank of Ghana Website, www.bog.gov.gh accessed on 02/03/09.

[9] Bascom, William R., 1952: The Esusu: a Credit Institution of the Yoruba. Journal of the Royal Anthropological Institute 82: 63-69.

[10] Baten, M. W. (2009, Oct). Vision of micro financing in Bangladesh: Success and challenges. Copenhagen Business School (Unpublished Master's thesis). Available at http://studenttheses.cbs.dk/ bitstream/handle/10417/796/waliul\%5Fbaten.pdf.

[11] Bjorkman M \&Svensson J. 2009. Power to the People: Evidence from a Randomized Field.

[12] Boahen, A. (1997) A study of its formation and Relations with its Neighbour. Thesis U C C.

[13] Boateng, D., (2009) Commercial Banks entering the Microfinance Market: Issues.

[14] Burkhauser, M., Metz, A, J. (2009) using coaching to provide on going support and supervision to Out-of -School Time Staff, implementing Evidence Based Practices in Out-of School Time Programs: The Role of Frontline Staff, [online] available at http://www.childtrends.org/files/childtrends20090111RbStaffCoaching.pdfaccessed july 2012

[15] CARE Access Africa. (2010). VSLAs linkage selection criteria. PrabhatLabh. (Dollar figures have been converted from Rwandan francs.) 
[16] CGAP (Consultative Group to Assist the Poor). (2009). "Focus on Deposits and Consumer Protection: A Silver Lining to the Crisis?" Article based on podcast interview with Elizabeth Littlefield, May 28.

[17] Christen, R., K. Lauer, T. Lyman, and R. Rosenberg. (2012). Microfinance Consensus Guidelines: A Guide to Regulation and Supervision of Microfinance. Washington, DC: CGAP. Development Study Monograph No. 4 and Columbus College of Education of Instruction. New York: Prentice Hall Inc. Economics 124:2. Experiment of a Community-Based Monitoring Project in Uganda. Quarterly Journal of Financial services for Women Entrepreneurs in the Informal Sector of Ghana, for Consideration, Business and Financial Timesfuture counseling.

[18] Gerald Pollio \& James Obuobi (2010), Microfinance Default Rate in Ghana: Evidence from Individual Liability credit contract.

[19] Ghartey, G. (2007). Sustaining Microfinance in Ghana: Implications of both Prudential and Non-prudential Regulations for the Sub-sector. Paper presented at the annual Microfinance Conference, University of Cape Coast, Ghana.

[20] Henderson, P., \& Gysbers, M, C. (2006) Providing Administrative and Counselling Supervision for school counsellors. (on-line) available at http://www.counsellingoutfit.com/Vistas0.6.35.pdf

[21] Ivancevich, J. M. (1998). Human resource management 7th ed. Boston: Irwin McGraw-Hill.

[22] Kimando, N. L., Kihoro M. J., and Njogu W. G. (2012) Factors Influencing the Sustainability of Micro-Finance Institutions in Murang'a Municipality, International Journal of Business and Commerce Vol. 1, No.10: Jun 2012[2145](ISSN: 2225-2436).

[23] Kohansal, M. R. and Mansoori, H. (2009). Factors Affecting on Loan Repayment Performance of Farmers in KhorasanRazavi Province of Iran. Conference on International Research on Food Security, Natural Resource Management and Rural Development, University of Hamburg, Germany. Retrieved on January 5, 2015 from http://www.tropentag.de/2009/abstracts/full/264.pdf

[24] Ledgerwood. J, Earne J., Nelson C (2013). The New Microfinancial Handbook, Washington DC 20433, The Bank 1818 H Street NW.

[25] Ledgerwood, J., White, V. (2006). Transforming Microfinance Institutions. Washington, DC: World Bank. Macmillan Publishing Company.
[26] Leedy, P. (1993). Practical research. New York: MacMillan Publishing Co.

[27] Microfinance in Africa (2013) Overview and suggestions for action by stakeholders. Retrieved on 27/12/2015;21:45 from united nation website of office of special advisor on Africa.

[28] Mills, D. Q (1997), real power to the people. Management Development

[29] The missing parts of microfinance: Services for consumption and insurance. SAIS Review 21, 61-70.

[30] Ntiamoah E. B., Oteng E., Opoku B., Siaw A., (2014). Loan Default Rate and its Impact on Profitability in Financial Institutions. Research Journal of Finance and Accounting, $5(14)$.

[31] Owusu D. A, Oppong A, Agyeiwaa D and Abruquah L., (2015) Reducing loan default rate among microfinancial institutions (MFI) in Ghana through innovative product design, delivery and efficient loan management. International journal of economics, commerce and management, Vol. 111, Issue 3, United Kingdom.

[32] Richard, V. (2007). Services for the Poor: What Work, Why and Where? Sri Lanka: Sri Lanka. Asian Development Bank.

[33] Rosenberg, R. (1996). "Microcredit Interest Rates." CGAP Occasional Paper 1. CGAP, Washington, DC.

[34] Rubin, A., \& Babbie, E. (2001). Research methods in social work (4th ed.). Pacific.

[35] Saunders M, Lewis P and Thornhill A. (2007), Research Methods for Business students(4th Edition).

[36] Seibel, H. D (2013) Microfinance in Nigeria: Origins, Options and Opportunities, Hahnwaldweg Köln/Germany, University of Köln.

[37] Strachan D. (2010). International stakeholder consultation report In Scale Project. Unpublished.

[38] Tanner and tanner, (1987), Supervision in Education Problems and Practices. New York.

[39] Warue, B. N., (2012). Factors affecting loan delinquency in Microfinance in Kenya. International Journal of Management Sciences and Business Research, 1(12). Working Paper 78, London.

[40] World Bank -Africa Region, Studies in Rural and Micro Finance, (1999), World Bank New York. 